専門医症例報告

咬合再構成により顎関節雑音を消失させ咀嚼障害が改善した症例

安陪 晋

\title{
A Case of Occlusal Reconstruction that Enabled the Release of Temporomandibular Joint Noise and Masticatory Disturbance
}

Susumu Abe

抄 録

症例の概要：患者は 60 歳の男性で，両側の顎関節雑音と咀嚼障害を主訴に来院した。下顎右側大臼歯欠 損部の補綴治療と下顎前方整位および咬合挙上を目的とした治療用義歯を作製した。主訴の改善を確認 し，経過観察を行った後，歯冠補綴と部分床義歯による咬合再構成を行なった。

考察：食事に支障をきたしていた復位性関節円板前方転位症例に対して，下顎前方位での咬合再構成を行 い良好な治療経過が得られた。本症例に対する咬合再構成は治療法として適切な選択であったといえる。 結論 : 両側性の相反性顎関節雑音症例に対し, 咬合挙上と下顎前方位での咬合再構成により, 症状が改善 した。今後さらに十分な経過観察が必要である。

和文キーワード

相反性顎関節雑音，咬合再構成，下顎前方整位

\section{ABSTRACT}

Patient: A 60-year-old male complained of reciprocal clicking on the bilateral temporomandibular joint (TMJ) and masticatory disturbance. A treatment denture was fabricated for the missing mandibular right molars. This denture was inserted to improve occlusal vertical dimension and for protrusive repositioning of the mandibular position. After improving the main complaint and a follow-up, we planned occlusal reconstruction with fixed prostheses and removal denture for the final prosthetic treatment.

Discussion: The provided occlusal reconstruction could release masticatory disturbance with temporomandibular joint disk displacement. In this case, a modification of the mandibular position with a prosthetic appliance was effective treatment.

Conclusion: Occlusal reconstruction and bite rising were applied to the patient with reciprocal clicking of the TMJ. Although he made satisfactory progress, long time follow-up with periodic and prosthodontic examination will be required in the future.

\section{Key words}

reciprocal clicking on the bilateral temporomandibular joint, occlusal reconstruction, removable partial denture, protrusive mandibular position 


\section{I。緒言}

復位を伴う顎関節円板の前方転位症例に対しての治療 方針は保存的治療法に主眼が置かれ，ゴールとしては関 節円板を正常な位置へ復位させることではなく，日常生 活に支障のない状態にもっていくこととされている ${ }^{1)}$. しかし，日常生活に支障がある場合には，下顎を前方に 整位し咬合再構成を行うことも治療の選択肢となり得 る.このような症例では，ただちに咬合再構成を行うの ではなく，治療用の装置で適切な顎位を慎重に決定しな ければならない ${ }^{1,2)}$. 今回，両側に相反性の顎関節雑音 を認める症例に対して, 下顎を前方に整位し咬合再構成 を行い，良好な治療経過を得たので報告する。

\section{II. 症例の概要}

患者: 60 歳 (本院来院時), 男性.

初診: 2003 年 8 月 18 日.

主訴：顎が鳴り人前で食事ができない.

既往歴: 腰椎の椎間板へルニアがあり, 薬物療法を中 心とした通院治療中である。ピリン系の薬剤に対するア レルギーがある。

現病歴：10 年前に埋入した 76 部インプラントが 2 年前に自然脱落し，しばらくして両側の顎関節に雑音を 自覚するようになつた。疼痛は認めないものの顎関節雑 音は大きく，他人に聞こえることが気になり，外食を控 えるようになった，近医を受診するか症状の改善が得ら れず，大学病院での治療を勧められたため来院した。

現症 : 両側の顎関節に開閉口中期でクリック音を認め る. 下顎前方位での開閉口運動で両側の関節雑音は消失 する. 最大開口量は $47 \mathrm{~mm}$ で, 触診では顎関節周囲 および咀嚼筋群において圧痛等は認められなかった。被 蓋は深く, 上顎前歯が下顎前歯を覆い隠すほどの過蓋咬 合を呈していた. オーバージェットは $3 \mathrm{~mm}$, オーバー バイトが $8 \mathrm{~mm}$ であった (図 1). 前方運動は 2 l|l 12 部が，側方運動は両側ともに犬歯部がガイドし，右側は $\mathrm{D}$ 型で左側は $\mathrm{M}$ 型のガイドであった。 3 には根尖病巣 が認められ，4 の周囲の歯槽骨は欠損しており, 歯周 病が進行していたが 5 と歯冠補綴装置で連結固定され ているため，動摇は認められなかった（図 2)。日常生 活の支障度はVAS 值で $67 \mathrm{~mm}$ であった（生活に支障 を感じない状態を $0 \mathrm{~mm}$ とし, 今までに経験した中で 最も辛い状態を $100 \mathrm{~mm}$ とする).

欠損形態は Kennedy 分類で Class II, Eichner 分 類は B1，宮地の咬合三角は第 I エリアであった。

診断: 下顎の後方偏位（図 3) ならび両側性顎関節症 IIIa 型と7 60欠損による咀嚼障害. 3 の慢性根尖性 歯周炎としの慢性辺縁性歯周炎による疼痛(違和感).
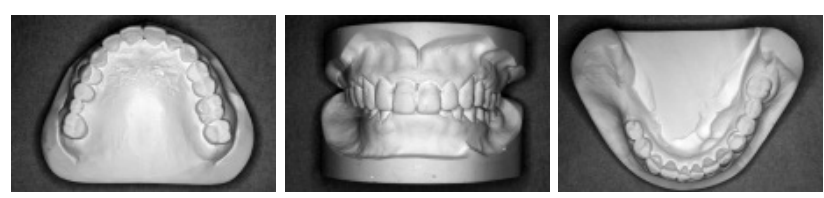

図 1 Study casts at first examination 初診時の診断用模型

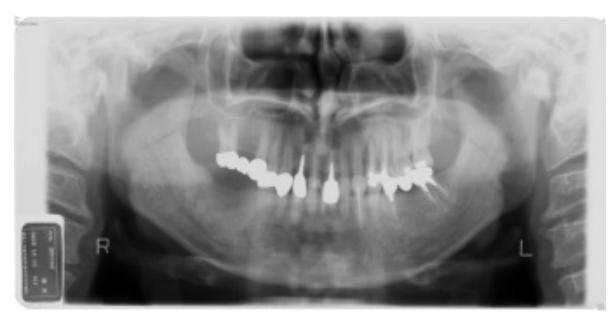

図 2 Orthopantomography at first examination 初診時のパノラマX $\mathrm{X}$ 線写真
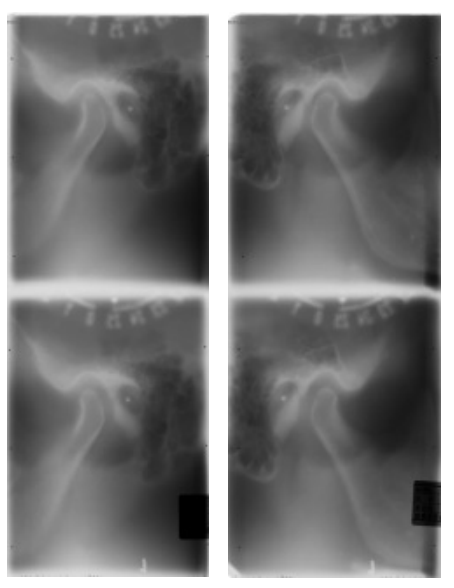

図 3 Temporomandibular joint tomography before treatment

Upper: intercuspal position, Lower: wearing stabilization splint.

術前の顎関節断層写真

上段：咬頭嵌合位，下段：Splint 装着時.

\section{III．治療内容と経過}

\section{1. 治療方針}

1）下顎前方位の開閉口で関節雑音の消失が認められ るため, スプリント治療とともに円板整位運動療法を行 い症状の改善を図る.

2）治療用義歯により下顎位の修正を行う.

3）接着性の補綴装置や暫間補綴装置を装着し，顎関 節の状態や顎関節雑音発現の有無の確認を行う。

4）最終補経装置を装着し咬合再構成を行う.

5）咬合再構成後のメンテナンスを行う.

以上の治療方針を患者に説明後，同意が得られたた 


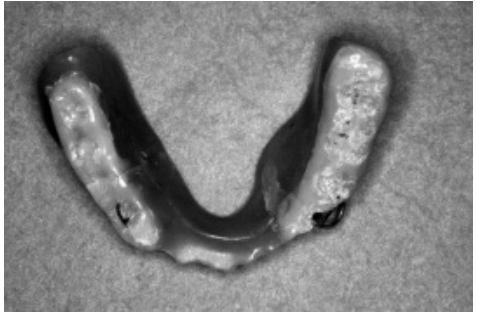

図 4 Lower removable partial denture for treatment to improve vertical dimension 咬合挙上のための下顎治療用義歯
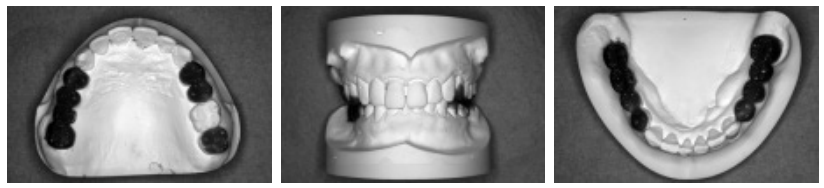

図 5 Diagnostic waxing up after improving vertical dimension

咬合高径の挙上後の診断用ワックスアップ

\section{め，この方針に沿って治療を進めることになった。}

\section{2. 治療内容}

問診より，日中の食いしばりや睡眠中のブラキシズム なども考えられたため, スタビライゼーションタイプの スプリントを上顎に装着し, 円板整位運動療法やリラク ゼーション指導を行った. スプリント装着約 1 カ月後, 睡眠中の下顎の後退を防ぎ，より確実に前方咬合位をと りやすくするために，リポジショニングタイプのスプリ ント（Rスプリント）に改変した。治療䫈位 (therapeutic position) は下顎の最前方咬合位から少しずつ下顎 を後方に移動させ，それぞれの下顎位での開閉口運動で 雑音が無くなることを確認しながら, 雑音を生じない位 置で本来の咬合位に近い位置とした ${ }^{1,2)}$. 同時期に， 3 の感染根管治療を開始した。

$\mathrm{R}$ スプリント装着後, 一時的に咀嚼筋の違和感と疲労 感を認めたが，生活に支障をきたすほどではなかった。 初診から約 4 力月半経過後, 日中に下顎前方位を保持 し，760欠損部を補うための治療用可撤性義歯を作 製し，下顎に装着した。この義歯は咀嚼力に耐えるため に，咬合面下レジン内にワイヤーのフレームを入れ補強 した（図 4).

義歯および R スプリントの調整をし経過観察を行っ た結果，義歯装着約 6 力月後に，下顎位も安定し関節 雑音も消失したため, 再度レントゲン撮影にて下顎頭の 位置を確認した。そこで，フェイスボーを用いて咬合平 面を確認し，この下顎位で咬合再構成を行った場合のモ ックアップ模型を作製した（図 5).

治療開始約 1 年後に 4 周囲歯肉が腫脹したため, 抜 歯を行った. その後も, 顎関節や周囲咀嚼筋群が安定し ていたため，モックアッブ模型を参考にし，(7)6 (5)|ブ

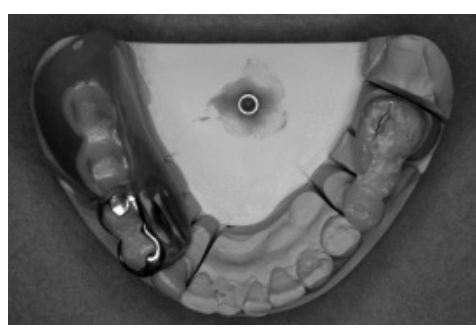

図 6 Lower provisional restoration and removable partial denture for treatment

下顎治療用の暫間補綴装置と義歯
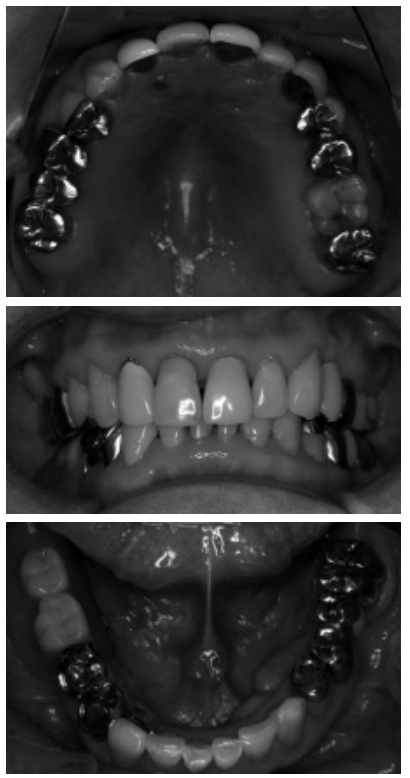

図 7 Intraoral views after insertion of the final restoration 最終補綴装置装着後の口腔内状態

リッジ，4|アンレー，(3) 4 (5)ブリッジ，|7アンレーの 治療を開始した。暫間補綴装置を装着し，上顎仮想咬合 平面と下顎位を再確認し，最終補綴装置を作製した。 た，」1 の硬質レジン前装冠が脱離したため，同時期に 再製した， R スプリントは内面を調整し，かつ下顎位が 同じ前方に保持できるようにした。

上顎の最終歯冠補綴装置を装着後， 543 と 4 およ び 5) 6 (7)に暫間補綴装置を装着し下顎位の安定およ び，顎関節への影響を観察した。また， 760 部分床 義歯に関しては暫間補綴装置に適合するように義歯を新 製した（図 6)。この状態で，下顎位は安定し，かつ両 側の顎関節雑音も認められなかつたため, 最終補綴装置 に置き換えた（図 7).

76 の部分床義歯に関しては，下顎隆起が発達して いることや，異物感を少なくして欲しいとの患者の要望 から，暫間義歯を片側性の部分床義歯とし経過観察を 行った。 その結果，義歯床下粘膜や鉤歯となっている 543 暫間補綴装置に異常を認めなかったため, 最終 
VAS值

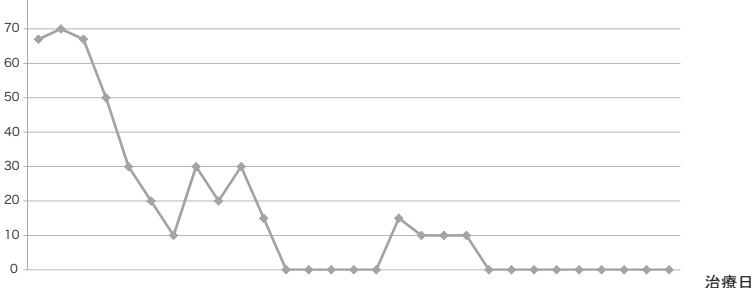

図 8 VAS values change the inconvenient degrees of daily life

日常生活の支障度を示す VAS 值の変化
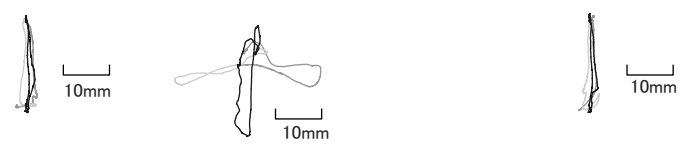

1

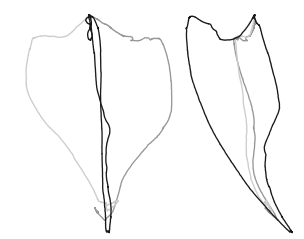

b

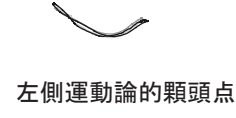

切歯点

図 9 Pathway of jaw border movement at four years after treatment with removable partial denture Sagital border movement (black), lateral border movement (gray).

治療終了後 4 年経時後の義歯装着状態での䫈運動

矢状面内限界運動（黒色）と側方限界運動（灰色）。

義歯も片側で処理することとした。このとき， $\overline{543}$ の歯冠補経装置の舌側部分をミリング処理し, 義歯の維 持・安定を図った。同時に R スプリントを新製し，義 歯非装着時にも下顎位が変化しないよう配慮した。

術前に比べて新たな咬頭嵌合位は垂直方向へ 3 $\mathrm{mm}$ ，前方方向へ $0.5 \mathrm{~mm}$ の位置に修正された。

\section{3. 治療経過}

2006 年 2 月下旬に最終補綴装置を装着し，一連の補 綴治療を終了した。患者は日常生活にも不自由を感じな いようになり，来院以前は関節雑音を気にして外食を控 えていたが，治療後は食事がおいしく摂れ，現在の状態 に十分満足しており, QOL の向上が認められた. 以降, 顎関節の症状や咬合のメンテナンスを開始し，翌年 5 月までは定期的に検診を行った。その間， 6 の遠心煩 側咬頭が破折したため, 形態修正し研磨を行った。その 後, 2009 年まで治療は中断し, 再来院時の口腔内診査 で5部のレストが破折していた。しかし，ミリング処 理がされていたため，義歯使用には支障がなかった。翌 年, 5 に違和感を生じ瘦孔形成が認められた。診査の 結果，歯根破折を起こしており，抜歯を行った。患者 は (4)5677ブリッジょりも 56 の部分床義歯を希望
し，左右別々の義歯を作製した。 2011 年 8 月現在，両 側の義歯の咬合状態および義歯床下粘膜の状態は安定し ており，特に違和感等を認めていない，顎関節の状態も 安定しており, 関節雑音の再発や QOL の低下および日 常生活の支障度を示す VAS 值の上昇もなく, 顎運動軌 跡も正常者と同様な像を示した ${ }^{3)}$ (図 8，9).

\section{IV. 考 察}

顎関節症IIIa 型に対し下顎前方位を最終的下顎位とし て咬合再構成を行った症例である。このような症例に は，㖽関節のみならず周囲咀嚼筋群の状態を十分に把握 しなければ，再構成を行ったとしても満足のいく結果は 得られないと考えられる。そのためにも，スプリントや 可撤性義歯および暫間補経装置を用いて顎関節の状態や 下顎位および咬合接触状態を観察し評価する必要があ る.今回, 暫間補綴装置を用いて経過観察を行った後に, 咬合再構成を行い，顎関節雑音を消失させ患者の QOL 向上に寄与できた。経過観察中に $\mid 6$ の咬頭破折，5の 義歯のレスト破折，5の歯根破折を生じたが，これは よく噛めるようになり大きな咬合力を発現するように なったことも原因の一つと考えられる.

\section{V. 結 論}

下顎の片側大臼歯部に欠損があり，両側顎関節に相反 性の関節雑音が認められた症例に対し，下顎前方位で咬 合再構成を行い，症状の改善を図った。咬合再構成は咬 合接触だけではなく，咬合力の方向や咬合力の大きさお よび顎関節部における構成要素の位置関係や負荷などに も変化をもたらすので，臨床症状はもとより，下顎運動 などを含めた総合的な観察が必要になってくる．特に咬 合接触については定期的に評価し，その変化を注意深く 観察することが重要と思われる。

\section{文献}

1）日本学関節学会編。顎関節症，大西正俊，飯塚忠彦， 亀山洋一郎, 渡辺 誠, 丸山剛郎監修, 京都 : 永末書店; 2003, 22-25, 136-139, 155-158, 276-278.

2）中野雅徳，坂東永一編。咬合学々歯科臨床．東京：医歯 薬出版; 2011,244-251.

3）大井啓司. 顎関節雑音を有する顎機能異常者の顎運動解 析. 補経誌 1993; 37:362-375.

著者連絡先 : 安陪晋

干770-8504 徳島県徳島市蔵本町 3-18-5

Tel: 088-633-9181

Fax: 088-633-9182

E-mail: susumu.abe@tokushima-u.ac.jp 